\title{
The Effect of Work Skills, Work Attitude, Work Knowledge on Work Competence and Employee Performance in Galaxy Mall Shuang Surabaya
}

\author{
Luvy Dian Mayasari ${ }^{1}$, Hermien Tridayanti ${ }^{2}$ \\ Narotama University Indonesia \\ luvydian02@gmail.com
}

\begin{abstract}
This study aims to analyze the influence of work skills, work attitudes, work knowledge on work competencies and analyze work skills, work attitudes, work knowledge on the performance of employees at the Shuang Galaxy Mall Surabaya.This study uses quantitative methods. By examining the effect of independent variables (work skills, work attitudes, work knowledge) on the dependent variable work competence and employee performance, the number of samples obtained was 41 people and analyzed using PLS (Partial Least Square) throughsoftware SmartPLS 3.0. The results of this study indicate that work skills, work attitudes, work knowledge have a significant effect on work competencies, work skills, work attitudes, work knowledge have a significant effect on employee performance and work competence has a significant effect on employee performance.
\end{abstract}

Keywords: Job skills, work attitude, work knowledge, work competency, employee performance

\section{INTRODUCTION}

In the era of globalization many people already know what SPA is, a place of beauty, body care, health and fitness. Using a holistic approach through comprehensive treatment with combination methods, skills, haydrotherapy, massage. The government has an important role so that it can help the development of the SPA industry which has proven that many companies have worked with the Indonesian SPA Association (ASPI). With the growth of the SPA industry, making the SPA business competition increasing from year to year, as now many SPA labels exist in Surabaya, a variety of massage techniques can create community interest so as to make people aware of their health and fitness.

Shuang Company - Galaxy Mall Surabaya is a service company that provides massage. By providing several massage techniques and treatment menus that can be selected by the customer as needed. Shuang also serves toddler massage with special treatments. To provide good service to customers and change the negative perceptions of the community about massage venues, companies must pay attention to the arrangement of rooms and employees, especially in the competence of therapist staff so as to provide customer comfort.

Skills. according to work skills (Wahyudi Bambang, 2002) are skills or expertise in doing a job only obtained from practice. Whereas according to (Gardon, 1994) skills are the ability to operate work easily and carefully.

Work attitude. Of labor attitudes (Robbbins and Judge, 2007a) is defined as as an evaluative statement, both pleasant and unpleasant towards objects, people or events. While (Kreitner and Kinicki, 2005) defines attitude as a tendency to respond to something consistently in supporting or not supporting by paying attention to certain objects. Capital adequacy

Knowledge of work. According to (Dunnette, 1976) Knowledge is the result of knowing, and this results after people do sensing a certain object.

Competency work. competency according to Spencer (Moeheriono, 2009) is a characteristic that underlies a person related to the effectiveness of individual performance in his work or basic characteristics of individuals who have causal or causal relationships with criteria that are referenced, effective or excellent or superior performance in the workplace or at certain situation. Whereas according to (Dharma, 2009) competence is what is carried by someone in work in the form of different types and levels of behavior. This must be distinguished from certain attributes (knowledge, expertise and expertise) needed to carry out various tasks related to a job.

Employee Performance. According to (Sedarmayanti, 2011) reveals employee performance is a translation of performance which means the work of a worker, a management process or an organization 
as a whole, where the results of the work must be shown concretely and can be measured (compared to predetermined standards )

Arif Eko Rakhmatullah, Sri Hadiati, Kohar Adi Setia, February 2018 the influence of Competence on Performance is not significant with a significance level of 0.623 and path cooficient values of -0.041 .

Bernard C. Renyut, H. Basri Modding, Jobhar Bima, St. Sukmawati, November 2017

competence is a positive and not significant effect on employee performance as mediated job satisfaction. (Mohamad Zaid Mustafa et al. 2014).

Based on the results of the empirical study above, there are gaps in the results of research, namely work competency has no significant effect on employee performance, work competencies should play a role in employee performance, therefore the authors are interested in reviewing work competencies measured by dependent variables employee performance, work skills, work attitudes, knowledge work.

\section{CONCEPTUAL FRAMEWORK}

1. 1.Relationship between the influence of work skills and work competencies Increasing work skills increases work competency.

2. Therel ationship between work attitudes and work competencies Increasing work attitudes will increase work competencies.

3. 3.Relationship between work knowledge and work competencies Increasing work knowledge increases employment competence.

4. 4.Relationship between work skills and employee performance Increasing work skills increases employee performance.

5. 5.The relationship between work attitudes and employee performance Increasing work attitudes will increase employee performance.

6. 6.Relationship between work knowledge and employee performance Increasing work knowledge increases employee performance.

7. The relationship between work competencies and employee performance Increasing work competencies increases employee performance.

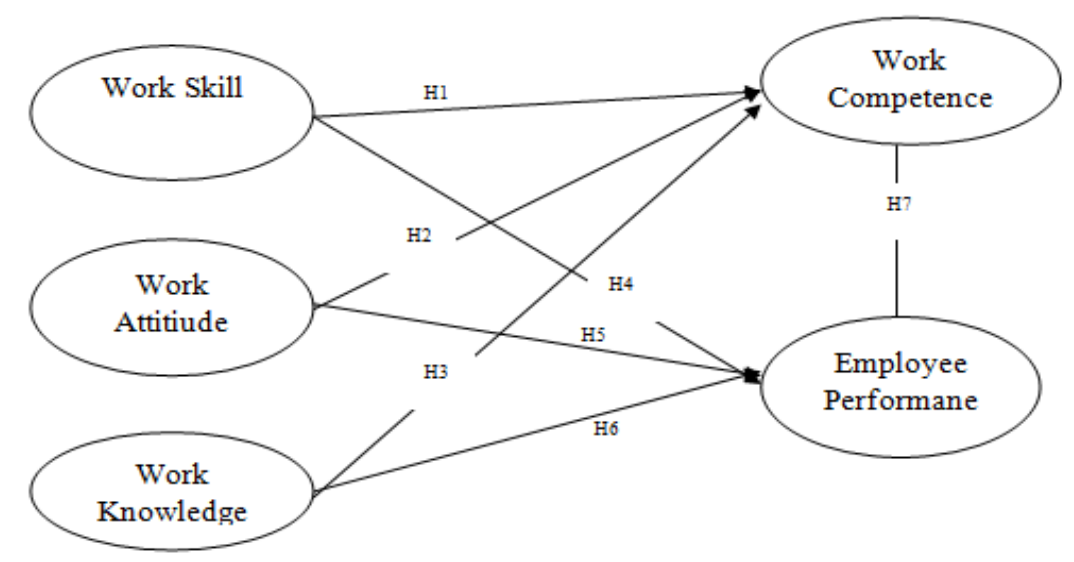

Figure 1: research concept framework

\section{METHODOLOGY}

This research uses a quantitative approach that is a lot of research that is demanded to use numbers, starting from data collection, interpretation of the data, and the appearance of the results. The variables of this study consisted of independent variables of work skills, work attitudes, work knowledge and dependent variables of work competence and employee performance.The population used by the 
population of all Shuang Galaxy Mall - Surabaya (census) employees was 41 respondents. Data analysisused techniquespartial leats square (PLS).

\section{RESULTS AND DISCUSSION}

Table 1: Path Coefficient.

\begin{tabular}{|l|c|c|c|c|c|}
\hline \multicolumn{1}{|c|}{ Path Coefficient } & $\begin{array}{c}\text { Original } \\
\text { Sample (O) }\end{array}$ & $\begin{array}{c}\text { Sample Mean } \\
\text { (M) }\end{array}$ & $\begin{array}{c}\text { Standard } \\
\text { Deviation } \\
\text { (STDEV) }\end{array}$ & $\begin{array}{c}\text { T Statistics } \\
(\mid \mathbf{O} / \text { STDEV|) }\end{array}$ & P Values \\
\hline $\begin{array}{l}\text { X1_Work Skills -> Y1_ Work } \\
\text { Competency }\end{array}$ & 0.255 & 0.271 & 0.107 & 2.385 & 0.009 \\
\hline $\begin{array}{l}\text { X1_ Work Skills -> Y2_ } \\
\text { Employee Performance }\end{array}$ & 0.184 & 0.181 & 0.090 & 2.048 & 0.022 \\
\hline $\begin{array}{l}\text { X2_Work Attitude -> } \\
\text { Y1_Work Competency }\end{array}$ & 0.297 & 0.289 & 0.128 & 2.311 & 0.011 \\
\hline $\begin{array}{l}\text { X2_Work Attitude -> } \\
\text { Y2_EmployeePerformance }\end{array}$ & 0.326 & 0.319 & 0.107 & 3.030 & 0.002 \\
\hline $\begin{array}{l}\text { X3_work knowledge -> Y1_Work } \\
\text { Competency }\end{array}$ & 0.445 & 0.437 & 0.143 & 3.121 & 0.001 \\
\hline $\begin{array}{l}\text { X3_ work knowledge -> } \\
\text { Y2_EmployeePerformance }\end{array}$ & 0.203 & 0.210 & 0.085 & 2.403 & 0.009 \\
\hline $\begin{array}{l}\text { Y1_ Work Competency -> } \\
\text { Y2_Employee Performance }\end{array}$ & 0.300 & 0.303 & 0.151 & 1.991 & 0.025 \\
\hline
\end{tabular}

Source: Processing data by smartPLS 3.0.

H1: The Effect of Job Skills on Job Competence

Based on the results of the analysis using smartPLS, it can be concluded that the results of hypothetical testing of work skills have a significant effect on work competency. The results of the first hypothesis test prove the $p$-value of 0.009 with a $t$ value of 2.385 . This value is greater than table $(1,688)$ and $p$-value below 0.05 . With this, it shows that the increasing work skills, the more work competencies will increase. H2: The Effect of Work Attitudes on Work Competence

Based on the results of the analysis using smartPLS, it can be concluded that the results of testing the working attitude hypothesis have a significant effect on work competency. The second hypothetical test results prove $\mathrm{p}$-value of 0.022 with a $\mathrm{t}$ value of 2.048 . This value is greater than $\mathrm{t}$ table $(1,688)$ and $\mathrm{p}$ value below 0.05 . This suggests that the increasing work attitude increases thework competency

H3: The Effect of Work Knowledge on Work Competence

Based on the results of the analysis using smartPLS, it can be concluded that the results of hypothesis testing of work knowledge have a significant effect on work competency. The third hypothesis test results prove $\mathrm{p}$-value of 0.011 with a $\mathrm{t}$ value of 2.311 . This value is greater than table $(1,688)$ and $\mathrm{p}$-value below 0.05 . With this, it shows that the more work knowledge increases, the more work competencies will increase.

H4: The Effect of Work Skills on Employee Performance

Based on the results of the analysis using smartPLS, it can be concluded that the results of the hypothesis testing of work skills have a significant effect on employee performance. The results of the fourth hypothesis test prove the p-value of 0.002 with a t value of 3.030 . This value is greater than $t$ table $(1,688)$ and p-value below 0.05 . The results of this study are in accordance with previous research from (Indri Tolo, Jantje L. Sepang, Lucky OH Dotulong) who said that work skills have a significant effect on employee performance. With this, it shows that the increasing work skills, the more employee performance increases.

H5: The Effect of Work Attitudes on Employee Performance

Based on the results of the analysis using smartPLS, it can be concluded that the results of testing the hypothesis of work attitudes have a significant effect on employee performance. The fifth hypothesis test results prove the value of $\mathrm{p}$-value of 0.001 with a $t$ value of 3.121 . This result is greater than $r$ table $(1,688)$ and p-value below 0.05 . The results of this study are in accordance with previous studies from (HAH Hettiararchchi, SMDY Jayarathna 2014) which said that work attitudes significantly influence 
employee performance. With this, it shows that the increasing work attitude increases the employee's performance.

H6: Effect of Work Knowledge on Employee Performance

Based on the results of the analysis using smartPLS, it can be concluded that the results of hypothesis testing of work knowledge have a significant effect on employee performance. The results of the sixth hypothesis prove that the $\mathrm{p}$-value is 0.009 with a $t$ value of 2,229 . This result is greater than t table $(1,688)$ and p-value below 0.05 . The results of this study are in accordance with previous research from (Milena Cvjetković, Dejan Djordjević, Dragan Ćoćkalo) who said that work knowledge had a significant effect on employee performance. With this shows that the more increasing work knowledge, the more employee performance increases.

H7: Effect of Job Competence on Employee Performance

Based on the results of the analysis using smartPLS, it can be concluded that the results of testing the work competency hypothesis have a significant effect on employee performance. The results of the seventh hypothesis test prove the p-value of 0.022 with a t value of 2.027 . This result is greater than $t$ table $(1,688)$ and p-value below 0.05. The results of previous studies from (Arif Eko Rakhmatullah, Sri Hadiati, Kohar Adi Setia,) said that work competency had no significant effect on employee performance. With this, it shows that the increasing work competency, thus increasing employee performance.

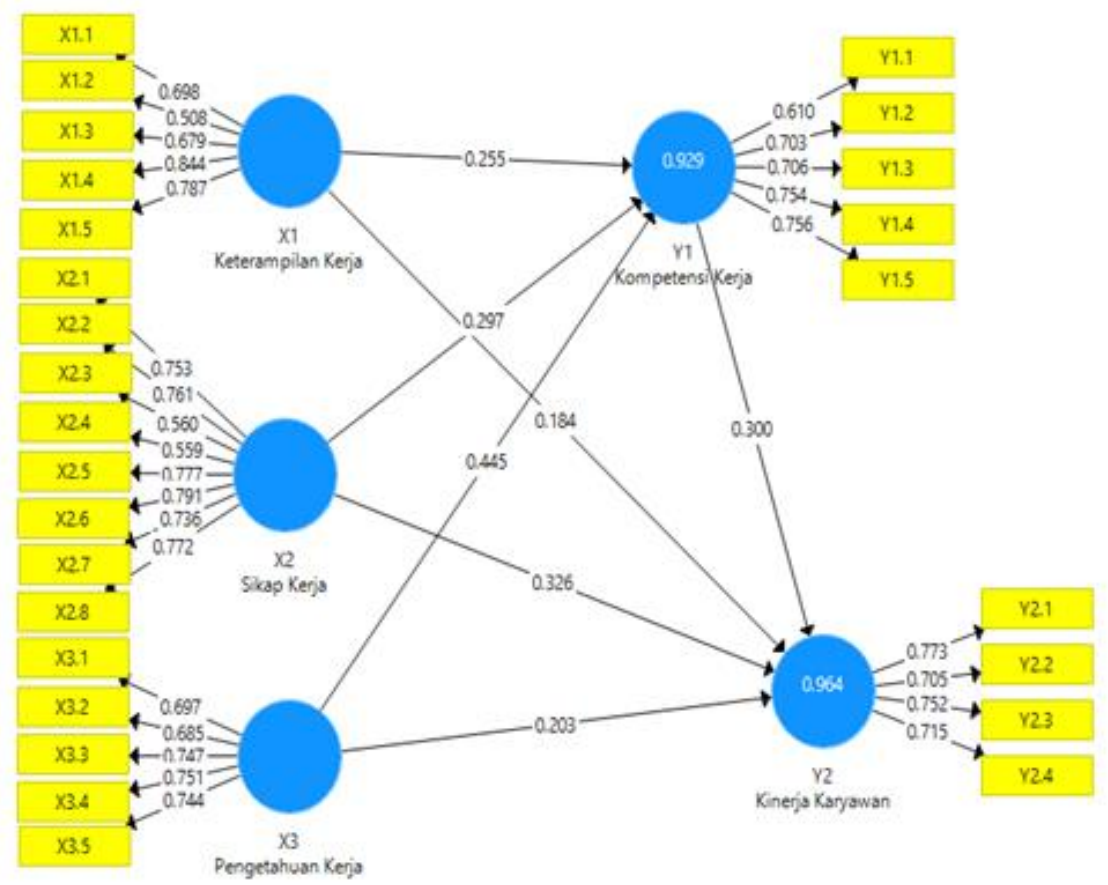

Figure 2: Structural Framework for Research

Table 2 Specific Indirect Effects

\begin{tabular}{|l|r|r|r|r|r|}
\hline & $\begin{array}{l}\text { Original } \\
\text { Sample } \\
\text { (0) }\end{array}$ & $\begin{array}{l}\text { Sample } \\
\text { Mean (M) }\end{array}$ & $\begin{array}{l}\text { Standard } \\
\text { Deviation } \\
\text { (STDEV) }\end{array}$ & $\begin{array}{l}\text { T Statistics } \\
\text { (|O/STDEV|) }\end{array}$ & P Values \\
\hline $\begin{array}{l}\text { X1_Work Skills -> Y1_- } \\
\text { Work Competency -> Y2_ } \\
\text { Employee Performance }\end{array}$ & 0.077 & 0.087 & 0.056 & 1.369 & $\mathbf{0 . 0 8 7}$ \\
\hline $\begin{array}{l}\text { X2_Work Attitude ->Y1_ } \\
\text { WorkCompetency-> Y2_- } \\
\text { Employee Performance }\end{array}$ & 0.089 & 0.084 & 0.053 & 1.685 & $\mathbf{0 . 0 4 8}$ \\
\hline $\begin{array}{l}\text { X3_work knowledge ->Y1_- } \\
\text { Work Competency -> Y2_ } \\
\text { Employee Performance }\end{array}$ & 0.134 & 0.131 & 0.079 & 1.683 & $\mathbf{0 . 0 4 8}$ \\
\hline
\end{tabular}




\section{Job Skills -> Work Competencies -> Employee Performance}

Based on the results of the analysis carried out using smartPLS, it can be concluded that the work skill variable (X1) has a negative and indirectly significant effect on employee performance (Y2) through work competence (Y1). This can be seen from the p-value of 0.087 less than 0.05 and the $t$-statistic value of 1.369 which is more than the $t$-table value of 1.688 . This shows that there is a lack of job skills training so that employees' competency and performance increase.

\section{WorkAttitude->WorkCompetence->EmployeePerformance}

Based on the results of the analysis carried out using smartPLS, it can be concluded that the work attitude variable (X2) has a positive and significant indirect effect on employee performance (Y2) through work competence (Y1). This can be seen from the p-value of 0.048 more than 0.05 and the t-statistic value of 1.685 which is less than the $t$-table value of 1.688 . This shows that the more work attitude increases the more work competency and employee performance

\section{Work Knowledge -> Job Competence -> Employee Performance}

Based on the results of the analysis carried out using smartPLS, it can be concluded that the work knowledge variable (X3) has a positive and significant indirect effect on employee performance (Y2) through work competence (Y1). This can be seen from the p-value of 0.048 less than 0.05 and the $t-$ statistic value of 1.683 which is more than the t-table value of 1.688 . This shows that the more knowledge increases the more work competencies and employee performance

\section{CONCLUSION}

Based on the results of the analysis that has been carried out and the discussion described in this study, the conclusions obtained are as follows:

1. Work skill variables have a calculated t-statistic value $<1.688$ which is 2.267 and $p$-value $>0.05$ which is equal to 0.012 . The results of the research hypothesis concluded that the variable work skills had a significant effect on work competencies in Shuang Galaxy Mall Suarabaya. Increasing work skills will increase work competence.

2. Variable work skills have a value of t-statistic $<1.688$ which is 1999 and p-value $>0.05$ which is equal to 0.023 . The hypothetical results of the study concluded that the variable work skills had a significant effect on employee performance at Shuang Galaxy Mall Surabaya. Increasing work skills will increase employee performance.

3. The variable work attitude has a value of t-statistic $<1.688$ which is 2.149 and the p-value $>0.05$ is equal to 0.016 . The results of the research hypothesis concluded that the work attitude variable had a significant effect on work competency at Shuang Galaxy Mall Suarabaya. The more work attitude increases, the more work competencies will increase.

4. Work attitude variables have a t-statistic count value $<1.688$ which is 2.882 and the value of p-value $>$ 0.05 is equal to 0.002 . The results of the research hypothesis concluded that the work attitude variable had a significant effect on employee performance at Shuang Galaxy Mall Suarabaya. Increasing work attitudes will increase employee performance.

5. Work knowledge variables have a t-statistic value $<1.688$ which is 2.901 and the p-value $>0.05$ is equal to 0.002 . The results of the research hypothesis concluded that the work knowledge variable had a significant effect on work competencies in Shuang Galaxy Mall Suarabaya. Increasing work knowledge will increase work competence.

6. The work knowledge variable has a t-statistic value $<1.688$ which is 2.229 and the p-value $>0.05$ is 0.013 . The results of the research hypothesis concluded that work knowledge variables had a significant effect on employee performance at Shuang Galaxy Mall Suarabaya. Increasing work knowledge will increase employee performance.

7. Variable work competency has a t-statistic value $<1.688$ which is 2.027 and the p-value $>0.05$ is equal to 0.022 . The results of the research hypothesis concluded that the variable work competence has a significant effect on employee performance. The more increasing work competencies, the more the employee's performance binds.

\section{REFERENCES}

[1] Wahyudi Bambang, Manajemen Sumber Daya Manusia. Bandung, 2002.

[2] Gardon, Keterampilan Pembukuan. Jakarta, 1994. 
[3] Robbbins Dan Judge, Perilaku Organisasi, 1 Dan 2. Jakarta, 2007.

[4] Kreitner Dan Kinicki, Perilaku Organisasi, 1 Dan 2. Jakarta, 2005.

[5] Dunnette, Keterampilan Pembukuan. Jalkarta, 1976.

[6] Moeheriono, Pengukuran Kinerja Berbasis Kompetensi. Bogor, 2009.

[7] Dharma, Manajemen Kinerja Falsafah Teori Dan Penerapannya. Yogyakarta, 2009.

[8] Robbbins Dan Judge, Perilaku Organisasi. Jakarta, 2007.

[9] Sedarmayanti, Manajemen Sumber Daya Manusia, Reformasi Birokrat Dan Manajemen Kepegawai Negeri Sipil. Bandung, 2011. 